ljtihad, Jurnal Wacana Hukum Islam dan Kemanusiaan

Vol. 16, No. 1 (2016), pp. 27-42, doi : 10.18326/ijtihad.v16i1.27-42

\title{
Rekonstruksi hukum kewarisan anak dari perkawinan sirri di pengadilan agama
}

\author{
Supriyadi \\ Jurusan syari'ah dan ekonomi Islam STAIN Kudus \\ E-mail:Supriyadi_rama@yaboo.co.id \\ DOI:10.18326/ijtibad.v16i1.27-42
}

Children born out of marriage Sirri has a different position with children from other marriages. Son of marriage Sirri, in the perspective of religion is legitimate, but legally is not recorded in the Office of Religious Affairs. The existence of child in the marriage Sirri must get legal certainty and the protection of law. Decision of the Constitutional Court (MK) has provided certainty and legal protection, but in a religious court the verdict has not been granted a constitutional manner. Therefore it is necessary to reconstruct the inheritance law of children born out of marriage Sirri by incorporating Court decision No. 46 / PUU-VIII / 2010 as a source of law in the legal system of inheritance in religious courts. Law should provide protection and legal certainty to the status of a child born out of marriage Sirri and rights available to him, although the validity of the marriage is still in question.

Anak yang lahir dari perkawinan sirri mempunyai kedudukan yang berbeda dengan anak dari perkawinan lainnya. Anak dari perkawinan sirri, dalam perspektif agama adalah sah, tetapi secara yuridis tidak dicatatkan di Kantor Urusan Agama. Keberadaan anak dari perkawinan sirri harus mendapat kepastian dan perlindungan hukum yang adil. Putusan Mahkamah Konstitusi (MK) telah memberikan kepastian dan perlindungan hukum tetapi di pengadilan agama putusan tersebut belum mendapatkan tempat secara konstitusional. Oleh karena itu perlu rekonstruksi hukum kewarisan terhadap anak yang lahir dari perkawinan sirri dengan memasukkan putusan MK No. 46/PUU-VIII/2010 sebagai sumber hukum dalam sistem hukum waris di pengadilan agama. Hukum harus memberi perlindungan dan kepastian hukum yang adil terhadap status seorang anak yang dilahirkan dari perkawinan sirri dan hak-hak yang ada padanya, meskipun keabsahan perkawinannya masih dipermasalahkan.

Keywords: Reconstruction; Inheritance law; Child; Sirri 
ljtihad, Jurnal Wacana Hukum Islam dan Kemanusiaan, Volume 16, No.1, Juni 2016: 27-42

\section{Pendahuluan}

Hukum kewarisan dibutuhkan oleh masyarakat karena berkaitan erat dengan aspek kehidupan manusia, khususnya apabila terjadi peristiwa hukum meninggalnya seseorang. Peristiwa meninggalnya seseorang, maka akan menimbulkan akibat hukum yaitu tentang bagaimana mengurus dan melanjutkan hak-hak serta kewajiban seseorang yang meninggal dunia tersebut. Persoalan baru biasanya muncul apabila orang yang meninggal tersebut meninggalkan harta kekayaan, yaitu berkaitan dengan peralihan pengelolaan ataupun pembagian terhadap harta kekayaan yang ditinggalkan atau harta warisan (Supriyadi, 2015: 554). Harta warisan inilah yang seringkali menimbulkan konflik di antara para ahli waris untuk memperoleh harta warisan dari pewaris.

Waris berasal dari bahasa Arab, Mirath bentuk mașdar dari Waritha-Yarithu-Warthan atau Irthan/ Turath, yang berarti mempusakai ketentuan-ketentuan harta pustaka yang meliputi ketentuan siapa yang berhak dan tidak berhak menerima warisan dan berapa jumlah masingmasing harta yang diterima (Ali Hasan, 1998:35) atau mawarith yang berarti harta peninggalan orang meninggal yang akan dibagikan kepada ahli warisnya. Hukum kewarisan Islam dikenal dengan istilah faraid, karena dalam Islam, bagian-bagian warisan yang menjadi hak ahli waris telah ditentukan dalam al-Qur'an. Hukum kewarisan Islam mendapat perhatian besar, karena pembagian warisan sering menimbulkan akibat-akibat yang tidak menguntungkan (Rofiq, 1995:355). Secara etimologis, faraid berasal dari kata fardh yang berarti taqdir (ketentuan). Dalam istilah syara' bahwa kata fardh adalah bagian yang telah ditentukan bagi ahli waris (Sabiq, 2006: 479). Secara terminologi hukum kewarisan dapat diartikan sebagai hukum yang mengatur tentang pembagian harta warisan yang ditinggalkan ahli waris, mengetahui bagian-bagian yang diterima dari peninggalan untuk setiap ahli waris yang berhak menerimanya (Rofiq, 1995: 355).

Menurut Soepomo (1966;25) hukum waris itu memuat peraturan-peraturan yang mengatur proses meneruskan serta pengoperan barang-barang harta benda dan barangbarang yang berwujud benda dari suatu angkatan manusia pada keturunannya. Kewarisan merupakan soal apakah dan bagaimanakah pelbagai hak-hak dan kewajiban-kewajiban tentang kekayaan seseorang pada waktu ia meninggal dunia akan beralih pada si hidup (Wiryono, tt:8). Hilman Hadi Kusuma (1986:12) menyatakan bahwa warisan menunjuk harta 
kekayaan dari orang yang telah meninggal, yang kemudian disebut pewaris, baik harta itu telah dibagi-bagi atau masih dalam keadaan tidak terbagi-bagi. Pasal 171 huruf (a) Hukum kewarisan adalah hukum yang mnegatur tentang pemindahan hak kepemilikan harta peninggalan (tirkah) pewaris, menentukan siapa siapa yang berhak menjadi ahli waris dan berapa bagiannya masing masing. Jika para pihak tidak saling menyadari tentang bagian masing masing maka dapat menimbulkan sengketa di antara para ahli waris bahkan dapat dibawa ke pengadilan.

Berdasarkan Undang-undang nomor 7 tahun 1989 jo. Undang-undang nomor 3 tahun 2006 jo. Undang-undang nomor 50 tahun 2009 tentang peradilan Agama, maka sengketa kewarisan merupakan kewenangan pengadilan agama. Sebagaimana diatur dalam Pasal 49 huruf (b) undang- undang peradilan agama yang menyatakan bahwa pengadilan adama bertugas dan berwenang memeriksa, menutus dan menyelesaikan perkara di tingkat pertama antara orang orang yang beragama Islam di bidang: Waris. Kewenangan ini tentu harus diikuti dengan kemampuan para hakim di pengadilan Agama tentang hukum kewarisan Islam. Sebenarya terhadap hukum kewarisan (faraị̣) yang telah diatur dalam al-Qur'an. Hal ini dapat diketahui bahwa ketentuan tentang pembagian harta warisan telah dirinci secara langsung oleh Allah SWT dalam al-Qur'an, hal ini terdapat dalam Surat al-Nisa', ayat 11, 12, dan 176.

Dari Surat al-Nisa' tersebut kedudukan anak sebagai ahli waris telah jelas pengaturannya bahkan di dalam Kompilasi Hukum Islam (selanjutnya disingkat KHI) juga telah jelas pengaturan kedudukan anak sebagai ahli waris sebagaimana diatur Pasal 174. Problematika timbul bukan karena memperdebatkan terhadap kewarisan anak yang telah diatur di dalam al-Qur'an atau dalam KHI tetapi terletak pada status anak. Apakah anak tersebut dilahirkan dalam perkawinan yang diatur dalam Undang- undang perkawinan nomor 1 tahun 1974 (dicatatkan) atau di luar undang- undang perkawinan yang sering diistilahkan dengan perkawinan sirri.

Sirri berasal dari bahasa Arab, sirrun yang berarti apa-apa yang dirahasiakan atau apa-apa yang disembunyikan dalam dirinya atau dalam jiwanya, kemudian masuk ke dalam perbendaharaan bahasa Indonesia yang oleh W.J.S. Poerwadarminta menyebutkan dengan kata-kata sir yang berarti ghaib atau rahasia atau sembunyi. Bahasa sirri selanjutnya dikaitkan 
ljtihad, Jurnal Wacana Hukum Islam dan Kemanusiaan, Volume 16, No.1, Juni 2016: 27-42

dengan perkawinan, menjadi perkawinan sirri. Perkawinan sirri dalam bahasa sehari-hari adalah perkawinan yang tanpa dicatatkan pada pegawai pencatat nikah, perkawinan ini dilakukan di depan modin atau kyai dengan dua orang saksi (terdapat ijab Qobul) atau dapat diartikan perkawinan tanpa ikatan hukum formil yang berlaku. dinyatakan tidah sah. Dapat dikatakan bahwa perkawinan sirri adalah sah menurut agama tetapi tidak sah menurut hukum negara karena tidak dicatatkan sebagaimana diatur dalam undang- undang nomor 1 tahun 1974 tentang perkawinan.

Pasal 2 undang-undang nomor 1 tahun 1974 disebutkan bahwa Perkawinan adalah sah, apabila dilakukan menurut hukum masing-masing agama dan kepercayannya dan tiap-tiap perkawinan dicatat menurut peraturan perundangan yang berlaku. Pencatatan perkawinan merupakan bukti otentik yang menentukan terhadap telah terjadinya perkawinan. Apabila perkawinan tidak dicatatkan secara legal formal, seseorang akan kesulitan ketika harus membuktikan bahwa ia telah melakukan perkawinan secara sah menurut hukum. Perkawinan sirri tidak memenuhi rumusan perundang-undangan ini maka perkawinannya merupakan perkawinan yang tidak sah, sehingga anak yang dilahirkanpun mempunyai kedudukan tidah sah menurut hukum formil, sebab dalam pasal 42 undang- undang nomor 1 tahun 1974 yang dimaksud anak sah adalah anak yang dilahirkan dalam atau sebagai akibat perkawinan sah, selanjutnya dalam Pasal 43 undang- undang perkawinan disebutkan bahwa anak yang dilahirkan di luar perkawinan hanya mempunyai hubungan keperdataan dengan ibunya atau keluarga ibunya.

Kedudukan anak ini berubah pasca putusan Mahkamah Konstitusi (selanjutnya disingkat MK) RI Nomor 46/PUU-VIII/2010 tanggal 27 Pebruari 2012. Perubahan tersebut berdasarkan Pasal 43 ayat 1 Undang- undang Perkawinan ini harus dibaca, "Anak yang dilahirkan di luar perkawinan mempunyai hubungan perdata dengan ibunya dan keluarga ibunya serta dengan laki-laki sebagai ayahnya yang dapat dibuktikan berdasarkan ilmu pengetahuan dan teknologi dan/atau alat bukti lain menurut hukum mempunyai hubungan darah, termasuk hubungan perdata dengan keluarga ayahnya. Oleh kerena itu, perlu dilakukan rekonstruksi terhadap hukum kewarisan anak dari perkawinan sirri di pengadilan agama.

Problematika timbul pada saat menentukan siapa ahli waris yang berhak mendapatkan harta peninggalan pewaris. Ahli waris terhadap anak sah telah jelas kedudukannya karena 
anak sah diatur dalam Pasal 2 jo. Pasal 42 undang- undang nomor 1 tahun 1974 tentang perkawinan. Hal ini berbeda dengan anak dari perkawinan sirri karena tidak memenuhi rumusan Pasal 2 jo. Pasal 42 undang- undang perkawinan. Namun demikian anak dari perkawinan sirri juga harus mendapatkan perlindungan hukum khususnya kepastian hukum terhadap proses pewarisan. Proses pewarisan merupakan cara bagaimana pewaris berbuat untuk meneruskan atau mengalihkan harta kekayaan yang akan ditinggalkan kepada para ahli waris dan bagaimana cara harta warisan itu diteruskan penguasaan dan pemakaiannya atau cara bagaimana melaksanakan pembagian warisan kepada para waris setelah pewaris meninggal dunia. Ketika ayah dari anak perkawinan sirri masih hidup mungkin tidak menimbulkan permasalahan hukum karena setidaknya ayah tersebut bisa memberikan nasehat kepada para calon ahli waris, tetapi ketika ayah telah meninggal tentu akan semakin kompleks permasalahannya. Hal ini disebabkan para ahli waris lain tidak mengakui keberadaan anak hasil perkawinan sirri pewaris, oleh karena itu perlu solusi yang secara hukum dibenarkan, sehingga tidak timbul permasalahan dikemudian hari.

\section{Kewarisan anak sirri sebelum putusan Mahkamah Konstitusi (MK)}

Menurut undang-undang nomor 1 tahun 1974, perkawinan sirri merupakan perkawinan yang belum memenuhi ketentuan Pasal 2 ayat (2) undang-undang perkawinan dan tidak diakui oleh kantor urusan agama walaupun perkawinan mereka telah memenuhi syaratsyarat yang telah ditentukan dalam Pasal 2 ayat (1) undang-undang nomor 1 tahun 1974, yaitu perkawinan yang dilakukan menurut agama dan kepercayaannya masing-masing. Perkawinan sirri tidak diakui keberadannya oleh negara, baik mengenai sahnya perkawinan maupun segala sesuatu akibat yang ditimbulkan dari perkawinan sirri tersebut. Anak sebagai akibat perkawinan sirri dalam hubungannya dengan undang- undang nomor 1 tahun 1974 hanya mempunyai hubungan keperdatan dengan ibunya atau keluarga ibunya sebagai mana yang diatur dalam pasal 43 ayat (1). Berdasarkan Pasal 43 ayat 1 undang- undang nomor 1 tahun 1974 sebelum adanya putusan MK ini maka anak yang lahir dari perkawinan sirri tidak mempunyai hubungan secara perdata dengan ayahnya atau keluarga ayahnya, meskipun dalam kenyataannya menurut hukum agama anak tersebut tetap diakui keberadaan oleh ayahnya beserta keluarga ayah. Sebenarnya tujuan utama perkawinan sirri dalam suatu 
masyarakat adalah antara lain untuk mencegah terjadinya perzinaan, mengikat keluarga yang satu dengan yang lain, menghindari pandangan yang tidak baik dari masyarakat sekitar, Agar putra-putrinya tidak terlalu bebas bergaul dengan pihak lain karenanya keduanya telah terikat tali perkawinan menurut agama maupun adat istiadat.

Pasal 42 undang- undang nomor 1 tahun 1974 yang mengatur mengenai sah tidaknya anak. Anak sah adalah anak yang dilahirkan di dalam atau sebagai akibat perkawinan sah. Dalam hal ini anak dari perkawinan sirri tidak memenuhi rumusan Pasal 42. Apabila selama perkawinan sirri berlangsung mempunyai harta, berupa harta bawaan ayah apabila dikaitkan dengan undang- undang nomor 1 tahun 1974, harta tersebut bukan jatuh pada anak melainkan jatuh pada pihak keluarga ayah, sebab anak yang dilahirkan dalam perkawinan sirri tersebut hanya mempunyai hubungan keperdataan dengan ibunya atau keluarga ibunya, sedang ayahnya tidak mempunyai hubungan apa-apa dengan anak tersebut. Sehingga proses pewarisan tidak dapat dilakukan apabila ayah dari anak perkawinan sirri telah meninggal dunia. Namun demikian pewarisan merupakan proses pengoperan harta warisan dari orang tua kepada anak, demikian juga terhadap anak yang lahir sebagai akibat perkawinan sirri pewarisan dilaksanakan secara berangsur angsur, yaitu saat orang tua masih hidup dengan cara hibah (Supriyadi, 2005). Proses pewarisan ini bila didasar pada ketentuan pada undangundang nomor 1 tahun 1974 dan hukum Islam bukanlah merupakan pewarisan melainkan penghibahan sebab penyerahan dilakukan saat orang tuanya masih hidup, sedang pewarisan harus merupakan peninggalan dari orang tua yang sudah meninggal dunia yang kemudian diturunkan kepada ahli warisnya.

Perkawinan sirri ini dikaitkan dengan undang- undang nomor 1 tahun 1974 bukanlah perkawinan yang sah walaupun sudah memenuhi syarat-syarat pada pasal 2 ayat (1) tetapi pasal 2 ayat (2) tidak terpenuhi maka perkawinan ini diangap tidak sah menurut hukum negara, sebab antara pasal 2 ayat (1) dan ayat (2) tersebut merupakan satu kesatuan yang tidak dapat dipisahkan, sehingga apabila salah satu unsur pasal tersebut tidak dipenuhi maka perkawinannya tidah sah menurut hukum (Rekso Wibowo, 1982:41). Maka dalam hal pembagian warisan anak dari perkawinan sirri, tidak mewaris harta peninggalan orang tuanya secara keseluruhan, anak hanya dapat memperoleh sebagian harta gono gini (harta bersama), dengan cara harta yang berupa harta bawaan dari ayah dan harta warisan yang 
dibawa ayah ke dalam perkawinan akan kembali kepada keluarga ayah, sedang harta gonogini yaitu harta yang diperoleh selama perkawinan berlangsung menjadi harta bersama yang kemudian dibagi menjadi dua, separoh akan diserahkan pada ayah atau keluarganya dan yang separoh lagi akan diserahkan kepada ibunya, sehingga anak dari perkawinan sirri ini menurut undang- undang nomor 1 tahun 1974 hanya dapat mewaris bagian dari ibunya sedang bagian dari ayahnya ia tidak akan dapat memperoleh melalui pewarisan (Supriyadi, 2005). Selanjutnya dikatakan bahwa KHI tidak menentukan secara khusus dan pasti tentang pengelompokan jenis anak, sebagaimana pengelompokan yang terdapat dalam hukum perdata umum. Dalam KHI selain dijelaskan tentang kriteria anak sah (yang dilahirkan dalam ikatan perkawinan yang sah), sebagaimana yang dicantumkan dalam Pasal 99 KHI, yang berbunyi bahwa anak yang sah adalah :

1. Anak yang dilahirkan dalam atau akibat perkawinan yang sah.

2. Hasil pembuahan suami isteri yang di luar rahim dan dilahirkan oleh isteri tersebut.

Anak yang lahir di luar perkawinan yang sah, seperti yang tercantum dalam Pasal 100 KHI bahwa anak yang lahir di luar perkawinan hanya mempunyai hubungan nasab dengan ibunya dan keluarga ibunya. Di samping itu, dijelaskan juga tentang status anak dari perkawinan seorang laki-laki dengan perempuan yang dihamilinya sebelum pernikahan. Sebagaimana yang tercantum pada Pasal 53 ayat (3) KHI : "Dengan dilangsungkannya perkawinan pada saat wanita hamil, tidak diperlukan perkawinan setelah anak yang dikandung labir". Demikian halnya Pasal 75 huruf (b) KHI menjelaskan tentang status anak dari perkawinan yang dibatalkan, yang berbunyi "Keputusan pembatalan perkawinan tidak berlaku surut terhadap anak-anak yang dilahirkan dari perkawinan tersebut. Pasal 162 KHI menjelaskan tentang status anak li'an (sebagai akibat pengingkaran suami terhadap janin dan/atau anak yang dilahirkan isterinya). Dengan demikian, KHI tidak ada mengelompokkan pembagian anak secara sistematis yang disusun dalam satu bab tertentu, sebagaimana pengklasifikasian yang tercantum dalam undang- undang Nomor 1 Tahun 1974.

\section{Kedudukan anak dari perkawinan sirri}

Putusan MK RI Nomor 46/PUU-VIII/2010 lahir karena adanya permohonan yudisial review yang diajukan oleh $\mathrm{Hj}$. Aisyah Mokhtar dan anaknya yang bernama Muhammad Iqbal 
ljtihad, Jurnal Wacana Hukum Islam dan Kemanusiaan, Volume 16, No.1, Juni 2016: 27-42

Ramadhan bin Moerdiono terhadap ketentuan Pasal 2 ayat (2) dan Pasal 43 ayat (1) Undangundang Nomor 1 Tahun 1974 tentang Perkawinan, dimana Moerdiono sebagai seorang suami yang telah beristri, menikah kembali dengan istrinya yang kedua bernama $\mathrm{Hj}$. Aisyah Mokhtar secara syari'at Islam dengan tanpa dicatatkan dalam register akta nikah, oleh karena itu ia tidak memiliki buku kutipan akta nikah, dan dari pernikahan tersebut lahir seorang anak laki-laki yang bernama Muhammad Iqbal Ramdhan Bin Moerdiono.

Anak yang lahir dari perkawinan sirri mempunyai kedudukan yang berbeda dengan anak luar kawin lainnya karena anak dari perkawinan sirri, dalam perspektif agama adalah sah, tetapi secara yuridis tidak dicatatkan di Kantor Urusan Agama. Dengan adanya putusan MK RI Nomor 46/PUU-VIII/2010, anak dari perkawinan sirri mempunyai akibat hukum yang berbeda dibandingkan dengan sebelum adanya putusan tersebut. Perbedaan tersebut dapat menyangkut tentang kedudukan anak, hak waris anak atau bahkan hubungan nasab dari ayah atau keluarga ayah. Uji materiil Pasal 43 ayat 1 Undang- undang Perkawinan dikabulkan karena hubungan anak dengan seorang laki-laki sebagai bapak tidak sematamata karena adanya ikatan perkawinan, akan tetapi dapat juga didasarkan pada pembuktian adanya hubungan darah antara anak dengan laki-laki tersebut sebagai bapak. Dengan demikian, terlepas dari soal prosedur/administrasi perkawinannya, anak yang dilahirkan harus mendapat perlindungan hukum, karena anak tersebut tidak berdosa dan kelahirannya di luar kehendaknya (Anwar, Munawar, http://www.badilag.net/data/artikel/artikel\%20nasab\%20anak\%20di\%20luar\%20perkawinan.pdf, diakses tanggal 14 Mei 2016). Berangkat dari uraian tersebut menarik untuk dikaji tentang kewarisan terhadap anak dari perkawinan sirri pasca putusan MK RI Nomor 46/PUU-VIII/2010.

Putusan MK RI Nomor 46/PUU-VIII/2010 Pasal 43 ayat 1 undang- undang perkawinan ini harus dibaca, Anak yang dilahirkan di luar perkawinan mempunyai hubungan perdata dengan ibunya dan keluarga ibunya serta dengan laki-laki sebagai ayahnya yang dapat dibuktikan berdasarkan ilmu pengetahuan dan teknologi dan/atau alat bukti lain menurut hukum mempunyai hubungan darah, termasuk hubungan perdata dengan keluarga ayahnya. Hal ini berakibat terhadap kedudukan anak dari perkawinan sirri dalam sistem hukum nasional. Perlindungan hukum terhadap anak perkawinan sirri ini menjadi penting karena secara agama pernikahan yang dilakukan oleh orang tua adalah sah menurut agama meskipun 
secara hukum negara perkawinan tersebut tidak diakui. Perubahan terhadap Pasal 43 ini sebenarnya terlepas dari pasal 2 tentang sah atau tidaknya perkawinan yang dilakukan oleh orang tuanya menurut undang undang. Hukum hanya ingin melihat kedudukan anak luar kawin (sirri) perlu mendapat perlindungan hukum dan kepastian hukum tentang status anak tersebut.

Atas permohonan tersebut MK berpendapat mengenai ketentuan Pasal 2 ayat (2) UU Nomor 1 Tahun 1974 tentang pencatatan perkawinan bahwa sesuai penjelasan umum angka 4 huruf b UU Nomor 1 Tahun 1974 MK menyimpulkan (1) pencatatan perkawinan bukan faktor yang menentukan sahnya perkawinan (2) pencatatan merupakan kewajiban administrasi yang diwajibkan berdasarkan perundang-undangan. Kewajiban kewajiban administrasi tersebut dapat dilihat dari dua perspektif, yaitu pertama dari prespektif negara, pencatatan dimaksud diwajibkan dalam rangka memenuhi fungsi negara untuk memberikan jaminan perlindungan, pemajuan, penegakan dan pemenuhan hak-hak asasi manusia yang bersangkutan yang merupakan tanggung jawab negara dan harus dilakukan sesuai prinsip negara hukum sebagaimana yang dimuat pada Pasal 28 ayat 4 dan ayat (5) UUD 1945. Sekiranya pencatatan tersebut dianggap pembatasan, maka pembatasan yang demikian tidak bertentangan dengan ketentuan konstitusi karena pembatasan dimaksud semata-mata untuk menjamin pengakuan serta penghormatan atas hak dan kebebasan orang lain. Kedua pencatatan secara administratif yang dilakukan oleh negara dimaksudkan agar perkawinan sebagai perbuatan hukum penting yang berimplikasi terjadinya akibat hukum yang sangat luas, dan dikemudian hari perkawinan itu dapat dibuktikan dengan bukti yang sempurna dengan suatu akta autentik. Oleh karena itu MK berpendapat bahwa Pasal 2 ayat (2) UU Nomor 1 Tahun 1974 tidak bertentangan dengan konstitusi. MK berpendapat mengenai anak yang dilahirkan di luar perkawinan yang dikonklusikan dengan anak yang tidak sah. Menurut MK secara alamiah tidak mungkin seorang perempuan hamil tanpa terjadinya pertemuan antara ovum dengan spermatozoa baik melalui hubungan seksual maupun melalui cara lain berdasarkan perkembangan teknologi yang menyebabkan terjadinya pembuahan. Oleh karena itu, tidak tepat dan tidak adil manakala hukum menetapkan bahwa anak yang lahir dari suatu kehamilan karena hubungan seksual di luar perkawinan hanya memiliki hubungan dengan perempuan tersebut sebagai ibunya (Syamsul Anwar, Isak Munawar. http://www.badilag.net/data/ 
ljtihad, Jurnal Wacana Hukum Islam dan Kemanusiaan, Volume 16, No.1, Juni 2016: 27-42

artikel/artikel\%20nasab\%20anak\%20di\%20luar\%20perkawinan.pdf, diakses tanggal 14 Mei 2016). Meskipun uji meteriil oleh MK terhadap Pasal 2 undang- undang perkawinan dinyatakan tidak bertentangan dengan konstitusi tetapi dalam pertimbangannya dikatakan bahwa pencatatan merupakan administratif dan sebagai alat bukti otentik telah terjadinya perkawinan dan bukan persyaratan tentang sah tidaknya suatu perkawinan. Sah atau tidaknya suatu perkawinan orang tua hukum tetap harus memberikan perlindungan terhadap anak yang dilahirkan, apalagi perkawinan sirri dianggap sah menurut hukum agama.

Perlindungan hukum terhadap anak luar kawin (sirri) tersebut dapat dilihat dengan dikabulkannya uji materiil Pasal 43 undang- undang perkawinan. Semangatnya, MK ingin menegaskan bahwa anak luar kawin pun berhak mendapat perlindungan hukum. "Hukum harus memberi perlindungan dan kepastian hukum yang adil terhadap status seorang anak yang dilahirkan dan hak-hak yang ada padanya, termasuk terhadap anak yang dilahirkan meskipun keabsahan perkawinannya masih disengketakan, demikian antara lain pertimbangan MK. Anak luar kawin, secara sederhana, diartikan sebagai anak yang dilahirkan seorang perempuan, sedangkan perempuan itu tidak berada dalam ikatan perkawinan yang sah menurut hukum dan agama dengan pria yang membuahinya. Dalam konsep hukum perdata, anak luar kawin itu bisa lahir dari orang tua yang salah satu atau keduanya terikat dengan perkawinan lain. Artinya, secara hukum, anak tersebut lahir dari hubungan zina. Pasal 44 ayat (2) undang- undang perkawinan memberi wewenang kepada pengadilan untuk memutuskan sah tidaknya seorang anak yang dilahirkan isteri berdasarkan permintaan salah satu atau kedua belah pihak. Hal ini dapat dilakukan ibu dan ayahnya sama-sama masih lajang, sehingga anak disebut anak luar nikah. Berdasarkan undang- undang perkawinan, anak yang sah adalah anak yang dilahirkan dalam atau sebagai akibat perkawinan yang sah. KHI menyebutkan seorang perempuan hamil di luar nikah hanya dapat dikawinkan dengan pria yang menghamilinya. Jika si pria menikahinya, maka anak yang lahir menjadi anak sah. Pasal 272 KUH Perdata juga menyebutkan demikian. Pengakuan si ayah terhadap anak biologisnya membawa konsekuensi adanya hubungan perdata (Pasal 280 KUH Perdata). Ibu dan/atau ayah dapat meminta ke pengadilan untuk mengesahkan status anak tersebut (Anwar, Munawar, http://www.badilag.net/data/artikel/artikel\%20nasab $\% 20$ anak $\% 20$ di\%20luar\%20perkawinan.pdf, diakses tanggal 14 Mei 2016). 
Pasal 43 ayat 1 UU Perkawinan dikabulkan karena hubungan anak dengan seorang lakilaki sebagai bapak tidak semata-mata karena adanya ikatan perkawinan, akan tetapi dapat juga didasarkan pada pembuktian adanya hubungan darah antara anak dengan laki-laki tersebut sebagai bapak. Dengan demikian, terlepas dari soal prosedur/administrasi perkawinannya, anak yang dilahirkan harus mendapat perlindungan hukum. Jika tidak demikian, maka yang dirugikan adalah anak yang dilahirkan di luar perkawinan, padahal anak tersebut tidak berdosa karena kelahirannya di luar kehendaknya. Dengan demikian, status anak dari perkawinan sirri harus juga diakui sebagai anak yang mempunyai hubungan keperdataaan dengan ayahnya atau keluarga ayahnya. Hal ini berdasarkan kenyataan bahwa anak hasil perkawinan sirri harus juga diterima oleh masyarakat bahwa ia juga mempunyai ayah sebagaimana umumnya (Supriyadi, 2005).

Komisi perlindungan anak Indonesia (KPAI) mengungkapkan hampir 50 juta anak di Indonesia tidak memiliki akta kelahiran karena berbagai sebab antara lain karena pernikahan tidak sah atau tercatat di atau kawin sirri, angka ini hampir separuh dari total jumlah anak di bawah 5 tahun yang ada di Indonesia. KPAI sangat mengapresiasi putusan MK beberapa waktu lalu yang mengabulkan permohonan uji materiil atas pasal anak diluar pernikahan sah dalam undang- undang perkawinan. Menurut ketua Komnas perlindungan Anak Aris Merdeka Sirait, perubahan pada Undang-undang Perkawinan oleh MK ini akan menjadi landasan hukum yang sah dalam memajukan upaya advokasi bagi anak-anak di luar pernikahan yang sah untuk memperoleh hak keperdataannya. Jadi putusan MK memberikan hak keperdataan yang selama ini tidak diakui negara. Makanya akta lahirnya itu tidak mencantumkan nama ayah. Dan tentu ini akan berimplikasi tidak mendapatkan hak waris dan tidak bisa mencantumkan siapa bapaknya, hal ini akan merugikan anaknya. Di dalam konvensi PBB juga pengakuan keperdataan dalam bentuk identitas nama dan kewarganegaraan itu harus diberikan oleh negara, tidak harus bergantung pada sah tidaknya perkawinan. Tetapi juga sebagai hak konstitusi, hak keperdataan, itu adalah hak yang sangat mendasar dan konstitusional" (Sofyan, http://www.jimlyschool.com/read/analisis/256/putusanmahkamah-konstitusi-tentang-status-anak-luar-kawin/ diakses tanggal 12 Mei 2016).

Alasan hukum yang melatarbelakangi penemuan hukum (rechtfinding) tersebut untuk menegaskan bahwa anak dari perkawinan sirri juga berhak mendapat perlindungan hukum. 
ljtihad, Jurnal Wacana Hukum Islam dan Kemanusiaan, Volume 16, No.1, Juni 2016: 27-42

Hal ini merupakan bentuk perlindungan hukum terhadap anak dari perkawinan sirri dan kepastian hukum yang berkeadilan. Hubungan darah antara anak dan ayah dalam arti biologis dapat dilegitimasi secara yuridis melalui penetapan pengadilan. Seorang ayah dari perkawinan sirri harus bertanggungjawab atas kelangsungan hidup anaknya, agar anak pun bisa memperoleh kasih sayang dan jaminan terhadap status hukum yang jelas.

Putusan MK suatu putusan yang bersifat final yang berkaitan dengan uji materil undangundang, yang dalam hal ini Pasal 43 ayat (1) Undang-Undang Nomor 1 Tahun 1974. Oleh karena itu, Putusan MK ini berlaku sebagai undang-undang sehingga substansinya general, tidak individual dan tidak kasuistik, sesuai ketentuan Pasal 56 ayat ((3) jo Pasal 57 ayat (1) undang- undang MK. Oleh karena itu putusan MK ini menjadi norma hukum yang berlaku untuk seluruh warga negara Indonesia tentang hubungan hukum antara anak dengan kedua orang tuanya beserta segala konsekwensinya terhadap anak dari perkawinan sirri ( Mukti Arto, 2012). Putusan Mahakamah Konstitusi tersebut memiliki kekuatan mengikat terhadap seluruh masyarakat Indonesia sejak diucapkan dalam sidang terbuka untuk umum pada tanggal 27 Pebruari Tahun 2012 sesuai Pasal 47 undang- undang MK dan dengan terbitnya putusan MK ini, maka ketentuan Pasal 43 ayat (1) dan Pasal 100 KHI tidak memiliki kekuatan hukum mengikat, dan harus dibaca sebagaimana putusan MK.

Putusan MK (MK) juga mencerminkan prinsip Persamaan di hadapan hukum (equality before the law) sebagaimana dimaksud dalam Pasal 28D ayat (1) yang berbunyi: "Setiap orang berhak atas pengakuan, jaminan, perlindungan, dan kepastian bukum yang adil serta perlakuan yang sama dihadapan bukum." Scheltema, merumuskan pandangannya tentang unsur-unsur dan asas-asas Negara Hukum itu secara baru yang meliputi 5 (lima) hal, salah satu diantaranya adalah prinsip persamaan dihadapan hukum, berlakunya persamaan (Similia Similius atan Equality before the Law) dalam negara hukum bermakna bahwa Pemerintah tidak boleh mengistimewakan orang atau kelompok orang tertentu, atau memdiskriminasikan orang atau kelompok orang tertentu. Di dalam prinsip ini, terkandung:

Pertama, adanya jaminan persamaan bagi semua orang di hadapan hukum dan pemerintahan, Kedua, tersedianya mekanisme untuk menuntut perlakuan yang sama bagi semua warga Negara. 
Dengan demikian hukum harus memberi perlindungan dan kepastian hukum yang adil terhadap status setiap anak yang dilahirkan dan hak-hak yang ada padanya, termasuk terhadap anak yang dilahirkan diluar perkawinan yang sah menurut peraturan perundang-undangan.

\section{Kewarisan anak Pasca putusan MK}

Pasca putusan MK menurut Mahfud MD menyatakan anak lahir di luar hubungan pernikahan atau di luar hubungan resmi tetap memiliki hubungan dengan ayahnya. Setelah adanya putusan ini, wanita bisa menuntut pria yang menghamilinya untuk memberi nafkah sang anak, sebagai bentuk pertangungjawaban ayah biologisnya. Perempuan juga bisa menuntut pria yang menghamilinya untuk menafkahi anaknya. Dengan dikabulkannya uji materi pasal ini, tidak lagi anak yang ditolak masuk lembaga pendidikan maupun lembaga formal lainnya akibat tidak memiliki keterangan siapa ayahnya. Secara resmi, MK sudah menetapkan bahwa anak yang lahir di luar perkawinan masih punya hubungan dengan ayah secara perdata. Kemudian, status anak tersebut tetap sah secara hukum. Dengan dikabulkannya uji materi tersebut merupakan angin surga bagi anak-anak yang lahir dari perkawinan (Muchtar, http:/ /www.merdeka.com/peristiwa/kisah-machica-mochtar-perjuangkan-anak-hasil-nikah-sirrike-mk.html, diakses 14 Mei 2016).

Apabila dilihat dari pengertian status anak diluar nikah yang telah di judicial review oleh MK maka gugatan dari Machica Mochtar, hanya satu yang dikabulkan Mahkamah Konntitusi, yaitu mengubah pasal 43 ayat 1 undang- undang perkawinan. Putusan ini mengakibatkan adanya hubungan perdata antara anak yang dihasilkan di luar pernikahan dengan ayahnya yang bisa dibuktikan dengan teknologi seperti test DNA. Jelas putusan ini mengundang kontra, karena dalam putusan yang dibacakan ini tidak dinyatakan bahwa anak hasil di luar pernikahan yang bisa meliputi anak hasil perzinaan, namun demikian berbeda jika anak hasil nikah sirri. Apalagi penjelasan dari pihak yang mengeluarkan putusan pun mengatakan bahwa yang dimaksud dengan di luar pernikahan adalah nikah sirri atau anak hasil perzinaan, kumpul kebo, selingkuh dan lain sebagainya yang penting anak tersebut bisa dibuktikan hubungan darahnya melalui teknologi yang canggih. Secara Islam, walaupun pernikahannya sirri tapi anak hasil pernikahan tersebut tetap memiliki hak yang sama dengan anak hasil pernikahan yang resmi oleh negara, memiliki hak waris dan hak perwalian karena anak tersebut tetap 
ljtihad, Jurnal Wacana Hukum Islam dan Kemanusiaan, Volume 16, No.1, Juni 2016: 27-42

dinasabkan kepada ayahnya. Berbeda halnya jika anak yang dihasilkan merupakan anak hasil seks bebas, tidak ada pernikahan/nikah sirri, maka anak hasil seks bebas inilah yang tidak memiliki hak waris dan hak perwalian. Orang-orang pengusung kebebasan tentu akan berargumen bahwa telah terjadi diskriminasi dan penelantaran terhadap anak hasil seks bebas. Padahal yang bersalah orang yang telah berzina tersebut (Haris, http:// www.negarahukum.com/hukum/status-anak-di-luar-nikah-menurut-hukum-perkawinannasional-dan-hukum-islam.html, diakses 12 Mei 2016).

Pasca putusan MK maka Pasal 43 ayat (1) undang- undang nomor 1 tahun 1974, hubungan di luar perkawinan itu tafsirannya dapat diperluas: Pertama, anak yang lahir melalui nikah sirri (karena hanya memenuhi tuntutan pasal 2 ayat (1) dan tidak memenuhi tuntutan pasal 2 ayat (2) undang- undang nomor 1 Tahun 1974. Kedua, anak yang lahir dari hasil kumpul kebo dan perzinaan atau sebab lain (tidak memenuhi tuntutan pasal 2 ayat (1) dan ayat (2) UU Nomor 1 Tahun 1974). Penanafsiran yang kedua, dalam perspektif maqashid al-syari'ah hal itu berbenturan dengan semangat hifdh al-Nafs, hifdh al-Nasl dan hifdh al-Din. Karena menjaga dan melindungi jiwa dan keturunan itu harus juga memperhatikan agama.

Majelis Ulama Indonesia (MUI) menilai Putusan MK No. 46/PUU-VIII/2010 tersebut sangat berlebihan, melampaui batas, dan bersifat "over dosis" serta bertentangan dengan ajaran Islam dan Pasal 29 UUD 1945. Putusan MK No. 46/PUU-VIII/2010 tersebut telah melampaui permohonan yang sekadar menghendaki pengakuan hubungan keperdataan atas anak dengan bapak hasil perkawinan, tapi tidak dicatatkan kepada Kantor Urusan Agama, menjadi meluas mengenai hubungan keperdataan atas anak hasil hubungan zina dengan lelaki yang mengakibatkan kelahirannya. MUI memandang, putusan MK tersebut memiliki konsekwensi yang sangat luas, termasuk mengesahkan hubungan nasab, waris, wali, dan nafkah antara anak hasil zina dan lelaki yang menyebabkan kelahirannya, dimana hal demikian tidak dibenarkan oleh ajaran Islam. Dalam Fatwa MUI No. 11 Tahun 2012 tentang kedudukan anak hasil zina dan perlakuan terhadapnya, menyatakan: "Anak hasil zina tidak mempunyai bubungan nasab, wali nikah, waris, dan nafaqah dengan lelaki yang menyebabkan kelabirannya." (Agung, http:/ / kuagunungjati.blogspot.com/2012/03/polemik-mui-dan-mksoal-anak-diluar.html diakses tanggal 13 Mei 2016 ). Perlu dipahami bahwa fatwa MUI ini bukan berlaku bagi anak hasil perkawinan sirri tetapi berlaku bagi akibat seks bebas atau 
perzinaan. Seks bebas sangatlah berbeda dengan perkawinan sirri karena perkawinan sirri telah memenuhi syarat rukunnya perkawinan, hanya saja tidak dicatatkan.

Hubungan keperdataan dalam perubahan Pasal 43 ini adalah mencakup dalam hal nasab, wali nikah dan waris, dengan catatan telah terjadi pernikahan sirri, tetapi jika tidak pernah terjadi pernikahan sirri maka anak hasil perkawinan tersebut juga tidak berhak atas kewarisan orang tuanya. Meskipun anak perkawinan sirri merupakan bagian dari anak luar kawin kerena tidak dicatatkan, tetapi apabila telah memenuhi syarat rukun yang telah ditentukan oleh agama, maka kewarisan anak perkawinan sirri dapat dipersamakan dengan anak perkawinan yang dicatatkan. Tidak dicatatnya perkawinan sebagaimana Pasal 2 tidak berarti menghilangkan hubungan anak dari ayahnya yang telah melakukan perkawinan sirri. Undangundang tidak secara jelas menguraikan maksud pencatatan, dalam penjelasan umum hanya dikatakan bahwa tiap tiap perkawina adalah sama halnya dengan pencatatan peristiwa peristiwa penting dalam kehidupan seseorang, misalnya kelahiran, kematian atau suatu akta resmi yang dimuat dalam daftar pencatatan. Perbuatan pencatatan tidaklah menentukan sah atau tidaknya perkawinan, tetapi menyatakan bahwa peristiwa perkawinan itu memang benar benar telah terjadi. Pencatatan tersebut semata mata hanya tindakan administrative (Supriyadi, 2015:51). Meskipun demikian perkawinan sirri merupakan perkawinan di bawah tangan yang keberadaannya tidak diakui oleh negara. Tidak diakuinya perkawinan sirri oleh negara ini tidak berakibat terhadap anak yang dilahirkan, sehingga anak tersebut tetap mendapat perlindungan hukum dalam hal kewarisannya.

\section{Penutup}

Rekonstruksi hukum kewarisan anak dari perkawinan sirri harus memasukkan putusan MK No. 46/PUU-VIII/2010 sebagai sumber hukum dan memberikan perlindungan hukum terhadap anak yang dilahirkan dari perkawinan sirri untuk memperoleh hak waris dari ayahnya. Perubahan Pasal 43 tidak melihat tentang sah atau tidaknya perkawinan orang tua, tetapi anak yang dilahirkan tetap mempunyai hubungan keperdataan dengan ayah dan keluarga ayahnya. Apalagi perkawinan sirri secara agama dianggap sah, sehingga secara sosiologis anak yang dilahirkan dapat diterima oleh masyarakat. Implikasi terhadap putusan MK ini menyangkut kedudukan anak di dalam hukum dan memberikan hak waris terhadap anak 
ljtihad, Jurnal Wacana Hukum Islam dan Kemanusiaan, Volume 16, No.1, Juni 2016: 27-42

yang dilahirkan dari perkawinan sirri. Kewarisan merupakan salah satu hak konstitusi anak dari perkawinan sirri untuk dipersamakan dengan anak sah lainnya.

\section{Daftar pustaka}

Hasan, M. Ali. Hukum Kewarisan Dalam Islam. Jakarta: Bulan Bintang, 1998.

Kusuma, Hilman Hadi. Hukum Waris Adat. Bandung, 1986.

Mukti, Arto A., "Diskusi Hukum Putusan MK RI Nomor 46/PUU-IIIV/2010 Tanggal 27 Pebruari 2012 Tentang Perubahan Pasal 43 UUP”, Bahan Diskusi Hukum hakim PTA Ambon dan PA Ambon Bersama Pejabat Kepanitreaan, di Auditorium PTA Ambon, tanggal 16 Maret 2012.

Projodikoro, Wiryono. Hukum Waris di Indonesia. Bandung: Vorkind Van Hoeve's Graven Hage, t.th.

Rahmulyo, Idris. Hukum Kewarisan Islam, Studi kasus ajaran Syafi'i, Hazairin (bilateral dan praktek di pengadilan Agama). Jakarta: Ind Hilco, 1984.

Rofiq, Ahmad. Hukum Islam di Indonesia. Jakarta: PT Raja GrafindoPersada,1995.

Sabiq, Sayyid. Fiqih Sunnah. Jakarta: Pena Pundi Aksara, 2006.

Soepomo. Bab-Bab tentang Hukum Adat. Jakarta: Universitas Indonesia Press, 1966.

Supriyadi. Dasar dasar Hukum Perdata di Indonesia. Semarang: Pustaka Magister, 2014.

Supriyadi, "Kedudukan Anak dari Akibat Perkawinan Sirri", Jurnal Judisia, edisi III (JuliDesember 2005).

Tjitrosudibio, Subekti. Kitab Undang-Undang Hukum Perdata dan Undang-Undang perkawinan Nomor_1/1974. Jakarta: Pradnya Paramita, 1999.

Wibowo, Rekso. Hukum Perkawinan Nasional. Semarang: Seksi Perdata Fakultas Hukum UNDIP, 1982.

Internet

Anwar, Syamsul, Isak Munawar, Kedudukan Anak Luar Kawin Pasca Putusan MK (fikih dan perundangan), bttp:/ / wmw.badilag. anak\%20di\%20luar\%20perkawinan.pdf, diakses tanggal 14 Mei 2016.

Sofyan, Syafran, Putusan MK tentang status anake luar kawin, http://www.jimlyschool.com/ $\mathrm{read} /$ analisis/256/putusan-mahkamah-konstitusi-tentang-status-anak-luar-kawin/ diakses tanggal 12 Mei 2016.

Muctar, Hasil perkawinan sirri, http:/ / www.merdeka.com/peristiwa/kisab-machica-mochtarperjuangkan-anak-hasil-nikah-sirri-ke-mk.html, diakses tanggal 14 Mei 2016

Naim, Haris, Anak luar nikah, http:// wmw.negarahukum.com/hukum/status-anak-di-luar-nikahmenurut-bukum-perkawinan-nasional-dan-bukum-islam.html, diakses tanggal 15 Mei 2016.

Agung, Ahmad, Polemik MUI dan MK terhadap anak luar kawin, http:/ / kuagunungjati.blogspot.com/ 2012/03/polemik-mui-dan-mk-soal-anak-diluar.html diakses tanggal 13 Mei 2016. 